\title{
Obszary pogórnicze w postindustrialnej transformacji Górnego Śląska
}

Górny Śląsk jest jednym z największych i najstarszych zagłębi górniczo-hutniczych w Europie. Przez wiele wieków przemysł był jednym z głównych czynników współtworzących i kształtujących jego krajobraz kulturowy. Można powiedzieć, że wszystko zaczęło się tutaj od przemysłu. Jednak dopiero ostatnie dwa stulecia pozostawiły w krajobrazie tej ziemi trwały ślad w postaci zakładów przemysłowych, osiedli robotniczych, wyrobisk górniczych, hałd czy innych specyficznych form terenu. Stanowią one unikatowe zabytki techniki, należące do dziedzictwa kulturowego i przyrodniczego, zarówno Polski, jak i Europy. Ukazując historię regionu, rozwój techniki, dorobek myśli naukowej oraz specyficzne śląskie tradycje, zwyczaje, decydują one o charakterze i odrębności tej ziemi i jej mieszkańców. Infrastruktura przemysłowa, przestarzała i uciążliwa, staje się obecnie dużą atrakcją turystyczna, przyciągającą zwiedzających. Spośród wielu wartości, które reprezentują te zabytki techniki, są one przede wszystkim przykładami wartości historycznych, źródłem badań naukowych oraz walorów uznawanych za emocjonalne, ale szczególnie istotnych, mianowicie wartości miejsca i świadomości. Są przykładem i egzemplifikacją myśli człowieka, materialnym urzeczywistnieniem jednego z ogniw rozwoju techniki i cywilizacji (Konopka 1994). Każda epoka tworzyła budowle na miarę swojej wielkości. Piramidy wznoszono na miarę potęgi jednostki, greckie świątynie czy średniowieczne katedry na miarę potęgi duchowej, zamki na miarę siły militarnej (Fletcher 1994). Podziemny labirynt wyrobisk górniczych, budynki kopalniane, huty i inne zakłady przemysłowe są niewątpliwie pomnikami potęgi gospodarczej. Są piramidami i katedrami przemysłowej rewolucji.

Współcześnie, gdy górnictwo odchodzi w przeszłość, likwidacji ulegają kolejne kopalnie, a niekiedy całe rejony górnicze, istnieją sprzyjające warunki, aby chronić nie tylko pomniki architektury, ale również stare, zabytkowe obiekty techniki górniczej. Ich adaptacja dla potrzeb podziemnych tras turystycznych może stanowić alternatywę w obliczu konieczności zamknięcia wyeksploatowanych podziemi. Kilkusetletnia działalność górnicza ukształtowała $\mathrm{w}$ wielu śląskich kopalniach unikalną architekturę podziemnego świata $\mathrm{w}$ postaci ołtarzy, rzeźb, płaskorzeźb, oryginalnej obudowy, podziemnych jeziorek czy nawet rzek. Ich niepowtarzalna sceneria stanowi naturalną podstawę i kompozycję do organizowania podziemnych tras turystycznych, do przedstawiania oryginalnych ekspozycji historii górnictwa, prezentowania okazów natury, specjalistycznych wystaw, a nawet spotkań okolicznościowych czy targów komercyjnych (Chmura, Lorenc, Mikoś 2002). Dostosowanie wyrobisk i innych podziemnych obiektów do potrzeb turystyki górniczej łączy się nierozerwalnie 
z ochroną konserwatorską tychże obiektów. Są one integralną częścią krajobrazu naturalnego i kulturowego regionu śląskiego. Ich zabezpieczanie i udostępnianie turystom jest ważnym elementem kulturotwórczym, ale również stanowi szansę aktywizacji gospodarczej regionu, miejscowości, na których się znajdują. Każde z nich ma indywidualny charakter, a ich struktura przestrzenna i naturalna decyduje o niepodważalnych wartościach historycznych, edukacyjnych i kulturowych.

Wykorzystanie spuścizny postindustrialnej, jako produktu turystycznego, będzie współtworzyć wielofunkcyjność regionu śląskiego, uczestniczyć w jego restrukturyzacji. Zmiana dotychczasowej funkcji starych zakładów z produkcyjnej na usługową podkreśla dokonującą się sukcesję funkcji tego obszaru - z sektora drugiego do trzeciego. Dzięki temu turystyka górnicza uczestniczy w tercjalizacji funkcjonalnej Górnego Śląska. Jako forma turystyki poprzemysłowej będzie dopełniała kierunek rozwoju regionu, uczestniczyła w swoistym ,„przełamaniu” jego monofunkcyjności.

Rozwijająca się turystyka górnicza stanowi ogromną promocję regionu, jego identyfikację poprzez spuściznę kulturową. Odzwierciedla ona lokalne tradycje i zwyczaje, które dają się łatwo odróżnić i zidentyfikować. W swoim zakresie turystyka ta nie obejmuje tylko przeszłości odwiedzanych miejsc, lecz także ukazuje współczesne oblicze oraz charakter dokonujących się przemian. Ziemia śląska jest niewątpliwie największym skupiskiem zabytkowych obiektów górniczych epoki industrializacji. Są one autentyczne i unikalne w skali europejskiej i światowej. Same w sobie zawierają ogromny ,potencjał atrakcyjności”, stanowiąc element tożsamości regionalnej. Różnorodność surowców, warunków geologicznych, sposobów eksploatacji w różnych wiekach, rodzaje zagrożeń w poszczególnych ośrodkach górniczych i metody radzenia sobie z nimi, pomysłowe rozwiązania techniczne ułatwiające pozyskiwanie surowców i ich transport, jak również wstępną obróbkę, rodzaje obudów górniczych wyrobisk, sztolni, przodków i szybów, sposoby wentylacji kopalń w różnych ośrodkach górniczych i różnych wiekach to tylko niektóre z walorów turystycznych (Lamparska-Wieland 2003). Dziś zabytki górnicze to miejsca, gdzie przeszłość spotyka się z przyszłością.

\section{PRZYKŁADY LOKALNYCH DZIAŁAŃ NA RZECZ OCHRONY ZABYTKÓW GÓRNICZYCH}

Na Śląsku, jak i w wielu rejonach Europy, zachowaniem i ochronązabytkowych obiektów poprzemysłowych zajmują się głównie miejscowe społeczności i organizacje. Są to bardzo cenne projekty, mające ponadlokalne oddziaływanie i globalny wydźwięk. Przykładem takiego działania jest utworzone w 1957 roku Stowarzyszenie Miłośników Ziemi Tarnogórskiej (SMZT), które dzięki entuzjastom i społecznikom, ich determinacji udostępniło dla turystów fragment podziemi tarnogórskich w Kopalni Zabytkowej Rud Srebronośnych oraz w Sztolni „Czarnego Pstraga”. Stanowią one relikt prawie 700-letnich dziejów górnictwa kruszcowego. Prowadzone są tu także badania naukowe, m.in. nad organizmami zasiedlającymi osłonięte środowiska złóż metali. Można obserwować formowanie się antropogenicznych środowisk zastępczych dla fauny jaskiniowej, w tym jednego z największych zimowisk nietoperzy w Polsce. Występują tu stanowiska dokumentacyjne zjawisk towarzyszących złożom kruszcowym. Możemy podziwiać zjawiska krasowe, unikalną szatę naciekową, jak perły jaskiniowe, kalcytowe i inne. Podziemia stały się również źródłem licznych inspiracji 
zarówno artystycznych, jak i edukacyjnych. Stowarzyszenie, uwzględniając szczególne walory historyczne i turystyczne Sztolni „Czarnego Pstraga” oraz Kopalni Zabytkowej wystąpiło w kwietniu 2002 roku do Ministerstwa Kultury o uznanie ich za Pomniki Historii. Oba obiekty zostały wpisane na tę listę w kwietniu 2004 roku. Prowadzone są również starania o wpisanie zespołu tarnogórskich zabytków związanych z górnictwem kruszcowym, w tym Kopalnię Zabytkową Rud Srebronośnych i Sztolnię „Czarnego Pstrąga”, na Światową Listę Dziedzictwa Przemysłowego UNESCO. Aktualnie kwestia ta nadal pozostaje otwarta.

Podobną rolę jak SMZT w Tarnowskich Gór, odgrywa powstałe w 1999 roku Stowarzyszenie Zabytkowej Kopalni „Ignacy” w Rybniku Niewiadomiu. Postawiło ono sobie za cel zabezpieczenie zabudowań kopalnianych i stworzenie placówki muzealnej gromadzącej pamiątki kultury i tradycji górniczej, związanych szczególnie z tą kopalnią, która jest najstarszym zakładem wydobywczym tego miasta. Powstała ona w 1792 r. i od tego czasu ciągle funkcjonuje. Organizowane przez Stowarzyszenie zwiedzanie kopalni jest wyrywkowe i ograniczone ze względu na wciąż trwającą eksploatację. Oprócz infrastruktury turystycznej na terenie zakładu mieszczą się również obiekty użyteczności publicznej. Obecnie w zabudowaniach dawnej kopalni znajduje się poczta i apteka. Program Stowarzyszenia zakłada, iż „Ignacy - Hoym” będzie nie tylko rodzajem skansenu przemysłowego, lecz także ma „żyć własnym życiem" zharmonizowanym z potrzebami środowiska lokalnego (Koncepcja utworzenia Muzeum... 2000). Korzystne jest ponadto otoczenie zabytkowego kompleksu. W jego sąsiedztwie znajdują się między innymi: dom kultury, kino, prywatny kort tenisowy. W pobliżu przebiega ponadto ścieżka rowerowa, zamykająca sieć ścieżek otaczających Rybnik.

Problematyką historii górnictwa węglowego na Śląsku zajmuje się, już od lat siedemdziesiątych XX wieku, Muzeum Górnictwa Węglowego w Zabrzu. Jest to do tej pory jedyna instytucja, która zajmuje się dziejami górnictwa węglowego tak kompleksowo. W 1993 roku Muzeum utworzyło Skansen Górniczy „Królowa Luiza”, gdzie zachował się układ przestrzenny kopalni z drugiej połowy XIX wieku wraz z częścią zabudowy i wyposażenia. Trwają także przygotowania do ponownego udostępnienia zwiedzającym Skansenu podziemnego „Guido”. Należy podkreślić, iż zespół dawnej kopalni „Guido” jest jedynym w Polsce zabytkowym zespołem z zachowanymi wyrobiskami poziemnymi reprezentującymi historię górnictwa węglowego przełomu XIX i XX wieku, a także jednym z nielicznych w Europie.

W 2000 roku zostało powołane do życia Stowarzyszenie „Pro Futuro” na rzecz restauracji i udostępnienia turystom zabrzańskiej Głównej Kluczowej Sztolni Dziedzicznej. Skupia ono miejscowych zwolenników i znawców z dziedziny górnictwa (górnicy, muzealnicy, naukowcy i przedsiębiorcy).

Urząd Miejski w Zabrzu i Muzeum Górnictwa Węglowego wspólnie podjęły się realizacji zadania pod nazwą: „Zabrze - śląski ośrodek kultury technicznej i turystyki przemysłowej”. Projekt ten obejmuje trzy etapy, związane z poszczególnymi obiektami:

- Etap „Królowa Luiza”,

- Etap „Główna Kluczowa Sztolnia Dziedziczna”,

- Etap „Guido”.

Władze miasta i województwa śląskiego podpisały w Zabrzu w grudniu 2003 roku porozumienie w sprawie realizacji tego przedsięwzięcia. Ma ono przede wszystkim na celu ochronę dziedzictwa przemysłowego miasta oraz innych cennych obiektów w Zabrzu oraz na Górnym Śląsku. Projekt ten stanowi przykład zgodnej współpracy nie tylko władz samorządowych województwa i miasta Zabrze, ale także regionalnych organizacji społecznych. 
Po realizacji wszystkich etapów planowane jest połączenie wymienionych powyżej obiektów w jedną instytucję kultury koordynowaną przez Muzeum Górnictwa Węglowego. Działania podejmowane w ramach tej inwestycji zostały wpisane zarówno w Strategię Rozwoju Miasta Zabrza, jak i województwa śląskiego na lata 2004-2013.

W swoim statusie ochronę, zachowanie podziemnych wyrobisk oraz ich prezentację posiada także Muzeum Miejskie „Sztygarka” w Dąbrowie Górniczej. W ramach jego działalności udostępniono turystom Sztolnię Ćwiczebną, która przez wiele lat służyła uczniom miejscowej Szkoły Górniczej. W chwili likwidacji ostatniej kopalni węgla kamiennego na terenie miasta - kopalni „Paryż”, sztolnia jest jedynym prawdziwym dokumentem świadczącym o rozwoju górnictwa w Zagłębiu Dąbrowskim. Sztolnia funkcjonowała jako obiekt turystyczny bardzo krótko, od września 2001 do czerwca 2002 roku. Ponownie jej zamknięcie było podyktowane względami bezpieczeństwa. Aktualnie trwają prace remontowe obiektu.

Inicjatywa ochrony podziemnych wyrobisk nie jest także obca w okolicach Częstochowy, gdzie kopalnictwo rud żelaza odegrało istotną rolę w gospodarczym i cywilizacyjnym rozwoju tego regionu. Pod koniec lat 70. utworzono tam Kopalnię Zabytkową na terenie likwidowanej Kopalni „Szczekaczka”. Mimo dużego zainteresowania obiekt ten został zamknięty w 1983 r. z uwagi na zbyt duże koszty pompowania wód dołowych. Dzięki staraniom środowisk górniczych udało się wybudować replikę kopalni w Parku Staszica przy Muzeum Miejskim. Obecnie trwają przygotowania do udostępnienia obiektu turystom. Działania te ujęto również w planach inwestycyjnych miasta do roku 2010.

\section{MotYwy ZWIEDZANIA KOPALNI ZABYTKOWYCH}

W celu poznania motywacji osób zwiedzających kopalnie zabytkowe przeprowadzono badania ankietowe w wybranych obiektach*. Wynika z nich duże zainteresowanie turystyką podziemną. Jest ona postrzegana jako coś nowego, źródło jedynych w swoim rodzaju przeżyć, o znacznych walorach edukacyjnych. Główną przyczyną przyjazdu do kopalni jest chęć zjazdu pod ziemię oraz możliwość zwiedzenia kopalni „z bliska” (ryc. 1). Dla przeciętnego turysty bowiem zjazd pod ziemię, przejście podziemnymi wyrobiskami, stanowi największą atrakcję, nowość zachęcającą do zwiedzenia. Wizyty w skansenie górniczym turyści nie traktują jedynie w kategoriach rozrywki. Turystyka ta wiąże się dla nich z dużym ,ładunkiem dydaktycznym". Możliwość zwiedzenia kopalni czy sztolni stanowi tak dużą atrakcję, iż podaje się go najczęściej jako główny motyw przyjazdu do danego regionu (ryc. 2).

Istotna jest nie tylko sama trasa turystyczna, jej wyposażenie, ale także przekazywane przez przewodnika informacje, ciekawostki, które pozwalają zwiedzającemu spojrzeć na górnictwo i jego dzieje z innej strony. Zróżnicowany komentarz dla poszczególnych grup wiekowych nadaje sens, jakość zwiedzaniu. Opowieści przewodnika stanowią swoisty niematerialny walor kulturowy podziemnych tras turystycznych, wzbogacając jednocześnie jego walory naturalne.

\footnotetext{
* Badania przeprowadzono na terenie Kopalni Zabytkowej Rud Srebronośnych, Sztolni „Czarnego Pstraga” w Tarnowskich Górach oraz Skansenu „Królowa Luiza” w Zabrzu. Do badań wykorzystano kwestionariusz ankietowy autorstwa M. Lamparskiej-Wieland oraz wyniki badań ze Sztolni „Czarnego Pstrąga” i Kopalni Zabytkowej w Tarnowskich Górach. Badania na terenie Skansenu „Królowa Luiza” w Zabrzu zostały przeprowadzone przez autorkę.
} 


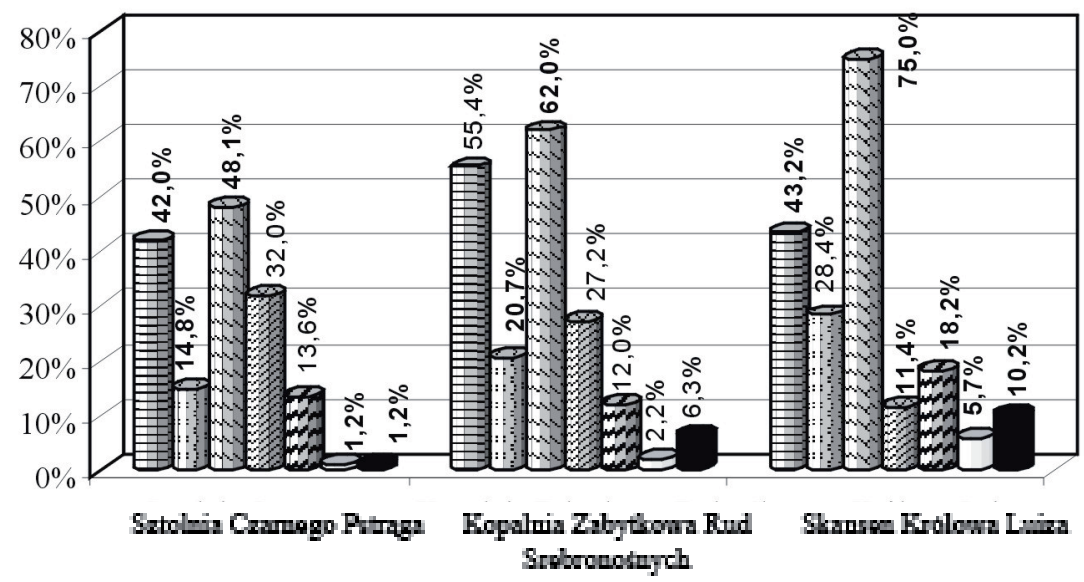

Dchqt pormanin crogot nowago

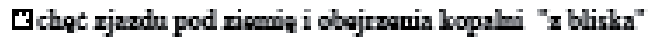

日chęc pozesmia dawnego gormictwa

Dchat przatycia nowego dotwiadczemia

S chęc pokarmis bliskim, rodrimis

口chęc sprawdzania siq

Dime motywy

Ryc. 1. Motywy zwiedzania kopalni zabytkowych przez turystów

Źródło: Opracowanie własne na podstawie badania ankietowego

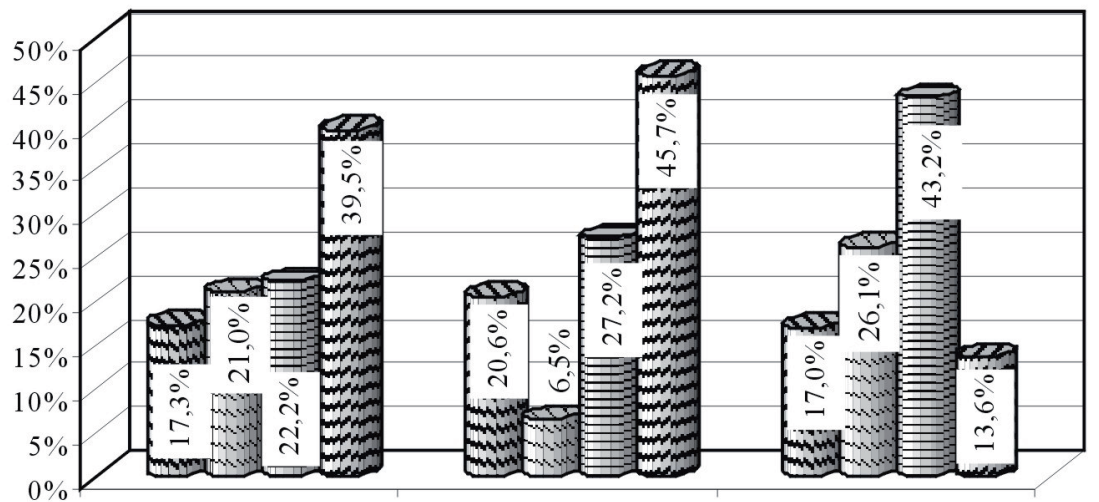

\section{Satolnia Czamego Prtraga Kopalnia Zabythowa Rud Skazan Krolowa Luina \\ Srobronotaych}

\section{Đprzypadkowa okazja}

口jedna $\mathrm{z}$ wazinych atrakcji turystyczuych
Øjedna $\mathrm{z}$ liczzych atrakcji turystycznych $\Delta$ glówny powód przyjazdu

Ryc. 2. Ranga atrakcyjności kopalni zabytkowej w stosunku do innych atrakcji regionu

Źródło: Opracowanie własne na podstawie badania ankietowego 
Śląskie skanseny stanowią ważne ośrodki regionalne, przyciąając przede wszystkim turystów z województwa śląskiego (średnio 61,6\%). Z pozostałych regionów największy odsetek zwiedzających pochodzi z sąsiednich województw: opolskiego, małopolskiego, wielkopolskiego oraz podkarpackiego. Zbyt małą rolę wśród źródeł informacji o kopalniach zabytkowych stanowią oferty biur podróży oraz lokalne punkty informacji turystycznej, które to właśnie w głównej mierze powinny promować własne obiekty kultury materialnej. Najważniejszym i najbardziej wiarygodnym źródłem informacji są opinie rodziny i znajomych (średnio 27\%). To one w zdecydowanej większości decydują o przyjeździe do danego obiektu.

Kopalnie zabytkowe stanowią przede wszystkim cel wycieczek szkolnych, które dominują w ogólnej strukturze zwiedzających we wszystkich obiektach. Odzwierciedla to również roczny rozkład ruchu turystycznego, który zwiększa się w miesiącach organizowania wycieczek szkolnych, tj. w maju, czerwcu i październiku. Na nasilenie frekwencji dużą rolę odgrywają ponadto imprezy organizowane na terenie kopalń, np. pikniki gwareckie, barbórki. O ich ponadregionalnym i międzynarodowym znaczeniu świadczy zwiększająca się liczba turystów zagranicznych.

Tabela 1. Segmentacja rynku turystyki przemysłowej

\begin{tabular}{|c|c|c|c|c|}
\hline $\begin{array}{c}\text { Typ } \\
\text { turystyki }\end{array}$ & $\begin{array}{c}\text { Rodzaj } \\
\text { aktywności }\end{array}$ & $\begin{array}{l}\text { Rodzaj } \\
\text { turysty }\end{array}$ & Motywacje & $\begin{array}{c}\text { Czas } \\
\text { pobytu }\end{array}$ \\
\hline $\begin{array}{l}\text { Turystyka } \\
\text { przemysłowa } \\
\text { (industrialna) }\end{array}$ & $\begin{array}{l}\text { - Zwiedzanie obiek- } \\
\text { tów. } \\
\text { - Wykłady w trak- } \\
\text { cie zwiedzania. } \\
\text { - Study tour. } \\
\text { - Uprawianie spor- } \\
\text { tów ekstremal- } \\
\text { nych (wspinaczki } \\
\text { na ścianach } \\
\text { obiektów, skoki } \\
\text { na linie, paintball, } \\
\text { jazda samochoda- } \\
\text { mi terenowymi, } \\
\text { np. na hałdach). }\end{array}$ & $\begin{array}{l}\text { - Młodzież szkolna } \\
\text { (koła zainteresowań). } \\
\text { - Studenci (np. historii, } \\
\text { kierunków technicz- } \\
\text { nych) krajowi i zagra- } \\
\text { niczni. } \\
\text { - Grupy naukowców } \\
\text { wraz ze studentami. } \\
\text { - Turyści krajowi i za- } \\
\text { graniczni segmentu } \\
\text { biznesowego, zaintere- } \\
\text { sowani inwestycjami } \\
\text { na obszarach poprze- } \\
\text { mysłowych. } \\
\text { - Turyści krajowi i za- } \\
\text { graniczni. }\end{array}$ & $\begin{array}{l}\text { - Poznanie historii. } \\
\text { - Edukacja techniczna. } \\
\text { - Aktywne odkrywa- } \\
\text { nie. } \\
\text { - Zdobywanie nowych } \\
\text { doświadczeń. } \\
\text {-,Przeżywanie” kon- } \\
\text { taktu z przeszłością. } \\
\text { - Utrwalanie za pomo- } \\
\text { cą fotografowania, } \\
\text { filmowania. } \\
\text { - Przeżycie przygody } \\
\text { oraz rozwój spraw- } \\
\text { ności fizycznej } \\
\text { (sporty ekstremalne). }\end{array}$ & $\begin{array}{l}\text { - Krótkie wy- } \\
\text { cieczki kilku- } \\
\text { godzinne. } \\
\text { - Wycieczki } \\
\text { jednodniowe. }\end{array}$ \\
\hline
\end{tabular}

Źródło: Strategia rozwoju turystyki... 2004

Pomimo zmniejszania się liczby zwiedzających w większości obiektów, turystyka górnicza ma duże szanse rozwoju. Podstawową rolę odgrywają tu jednak nie tylko fundusze, ale głównie współpraca lokalnych społeczności na rzecz zachowania regionalnego dziedzictwa poprzemysłowego. Wystawy, koncerty, pikniki oraz inne imprezy kulturalne stanowią ogromny „magnes” przyciagający turystów. Świadczy o tym przykład Skansenu „Królowa Luiza", która jako jedyny odnotowuje wzrost turystów. Ważny czynnik w tym przypadku stanowiło włączenie kopalni do programu „Zabrze - śląski ośrodek kultury technicznej i turystyki przemysłowej”. Działania w ramach programu, liczne inicjatywy kulturalne oraz promocja obiektu znalazły odbicie we wzrastającej frekwencji. 
Istotne jest stałe poszerzanie oferty turystyki industrialnej. Zabytki poprzemysłowe oraz rozległe tereny je otaczające stanowią niewyczerpane źródło inspiracji, możliwości wykorzystania na nowe cele: rekreacyjne (np. ścianki wspinaczkowe w opuszczonych budynkach poprzemysłowych), edukacyjne (np. organizacja zajęć szkolnych w podziemiach zabytkowych kopalń), komercyjne (np. kina, centra handlowe) czy biznesowe (np. biura, sale konferencyjne) (tab. 1).

\section{TURYSTYKA GÓRNICZA SZANSĄ AKTYWIZACJI GOSPODARCZEJ GóRNEGo ŚLĄSKA}

Turystyka przemysłowa może stanowić istotny stymulator rozwoju gospodarczego województwa śląskiego, przyczyniając się do aktywizacji innych gałęzi gospodarki. Świadczą o tym udane przykłady rewitalizacji zabytków techniki za granica, jak np. Yorkshire w Wielkiej Brytanii, Północna Nadrenia - Westfalia (IBA - Emscherpark) i Saksonia - Anhalt (Ferropolis) w Niemczech, czy Nord-Pas de Calais we Francji. Według specjalistów ze Światowej Organizacji Turystyki (WTO) wynika, że 1 miejsce turystyczne (stałe) generuje zatrudnienie dla 10 osób (Strategia rozwoju turystyki... 2004). Dochody z turystyki zasilają budżety gmin w sposób bezpośredni (podatki od nieruchomości, gruntów, opłata klimatyczna itp.) oraz pośredni (wynikające z rozwoju innych działalności). Występuje tu tzw. zjawisko mnożnikowe - wydatki turystów generują przychody różnych podmiotów gospodarczych, związanych bezpośrednio lub pośrednio z turystyką.

Kopalnie zabytkowe, jak i cały otaczający je krajobraz pogórniczy stanowią ogromną atrakcję turystyczną, ale gdy już są częściowo zrekultywowane, przemodelowane. Zagospodarowanie tych terenów i obiektów jest najnowszym trendem w kreowaniu przestrzeni architektonicznej. Posiadając niepowtarzalne walory przestrzenne, plastyczne mogą stanowić element rozwoju zarówno całego regionu, jak i poszczególnych miejscowości, zachowując autentyczny krajobraz kulturowy. Rewitalizacja, ochrona i adaptacja dla współczesnych funkcji dawnych obiektów techniki górniczej jest także dużą szansą dla ekonomicznego rozwoju lokalnych społeczności, może stać się miejscem ich integracji, wizytówką danej wspólnoty, przyciągającą turystów z kraju i z zagranicy. Ze względu na swoją specyfikę podziemne trasy turystyczne są obiektami przygotowanymi do zwiedzania przez cały rok. Duże szanse dla rozwoju stanowi możliwość połączenia, zintegrowania turystyki górniczej z innymi formami spędzania wolnego czasu (np. turystyka miejska, kulturowa, agroturystyka) oraz wzrastające zapotrzebowanie na turystykę kwalifikowaną (w Polsce i na całym świecie), której jedną z odmian jest turystyka podziemna.

Górny Śląsk, tak silnie niegdyś uprzemysłowiony, a obecnie podlegający procesom dezindustrializacji, wymaga działań przede wszystkim o charakterze kompleksowym. Tylko wówczas mogą być one skuteczne. Zaadaptowanie starych zakładów przemysłowych do innych niż pierwotne cele, może stać się „lekarstwem” na wiele problemów wynikających ze zmian strukturalnych. Generują one bowiem nowe miejsca pracy, pozwalają zachować jakże ważną regionalną tożsamość, stając się ponadto istotną częścią tego krajobrazu. Wiele z nich służy nie tylko turystom, jako obiekt do zwiedzania, lecz same stają się miejscem licznych imprez o charakterze kulturalnym czy rozrywkowym. Zrozumienie mechanizmów tychże działań 
jest niezwykle cenne. Nie można bowiem przenosić konkretnych rozwiązań na inny obiekt, gdyż każdy posiada odmienne warunki lokalizacyjne, techniczne oraz ekonomiczne. Istotne jest zrozumienie, iż sukces danego projektu nie jest możliwy bez zgodnej współpracy polityków, samorządowców, projektantów i społeczników. Jest to warunek konieczny dla skutecznej realizacji działań.

Możliwość ochrony i zachowania zabytków techniki nie zależy wyłącznie od ich tradycyjnego pojmowania. Fundusze odgrywają bardzo ważną rolę i są decydującym czynnikiem w efektywnej ochronie zabytków. Świadomość i wyobraźnia musi się łączyć z rachunkiem ekonomicznym. Niemniej jednak istotne jest, by umieć z tych funduszy umiejętnie korzystać. Nie można przeznaczać bowiem milionów sum na wyburzanie wartościowych i unikalnych obiektów, a nic na ich zabezpieczanie, jak to się dzieje nierzadko na Śląsku.

Udana rewitalizacja w głównej mierze zależy od zmiany stosunku społeczeństwa do dziedzictwa przemysłowego. Nowe postrzeganie krajobrazu kulturowego, nowe rozumienie piękna własnego regionu jest często ważniejsze niż sama infrastruktura techniczna. Dzięki niemu mieszkańcy odkrywają niezauważane wcześniej walory środowiska, w którym żyją, a które wcześniej postrzegali jako silnie zdegradowane i bez szans na przyszłość. Zwiększające się zainteresowanie dziedzictwem poprzemysłowym na świecie, jego adaptacja do nowych celów, świadczyć może o jego dużym potencjale turystycznym oraz o sprzyjających warunkach do rozwoju turystyki industrialnej, nie tylko za granica, ale również w Polsce. Doświadczenia krajów zachodnich w dziedzinie ochrony obiektów poprzemysłowych mogą służyć polskim organizacjom i stowarzyszeniom, podejmujących się tworzenia podziemnych tras turystycznych, muzeów techniki, czy nadawaniu nowych funkcji dawnym zakładom. Kraje, w których najwcześniej rozpoczęła się era przemysłowa, pierwsze zetknęły się z problemem ochrony zabytków techniki. Każdy wypracował własne metody postępowania, pozwalające na zachowanie najbardziej cennych i wartościowych obiektów. Korzystając z doświadczeń naszych poprzedników, możemy uzyskać cenne wskazówki.

Głównymi barierami w rewitalizacji i ochronie zabytków techniki są:

- brak aktualnych przepisów prawnych, chroniących tego rodzaju obiekty, ich unikatowe wyposażenie w związku z dokonującymi się przekształceniami własnościowymi w górnictwie;

- niewystarczająca infrastruktura do realizacji funkcji turystycznej;

- niedostateczna promocja turystyki przemysłowej, słaba współpraca z biurami podróży;

- brak funduszy na rewitalizację i ochronę zabytków górniczych;

- zły stan zachowania obiektów oraz ich wyposażenia technicznego.

Dostosowanie starych kopalń dla celów turystycznych wymaga nie tylko wielkich nakładów finansowych, ale także determinacji i zaangażowania społecznego. Niezbędna jest sama chęć ich zachowania. Zbyt często traktowane są one jako coś szpetnego, zbędnego, widziane przez pryzmat „tradycyjnej kultury”, zamiast dostrzec w nich ogromny potencjał, wyjątkowe wartości estetyczne. Należy zaczać je traktować jako swoisty „znak firmowy” regionu śląskiego, z którym społeczeństwo może się identyfikować.

Przeobrażenia strukturalne regionu to proces wieloletni, który wymaga zmiany mentalności społeczeństwa, postrzegania przez nie obiektów poprzemysłowych, ale również przekształceń ekonomicznych (m.in. struktury zatrudnienia), technicznych, komunikacyjnych, funkcjonowania administracji publicznej (urzędy miejskie, wojewódzkie itp.), form ochrony przyrody. Nierozerwalnie wiąże się on z konfliktami społecznymi, dlatego też tak ogromną 
rolę odgrywają konsultacje z lokalną społecznością. Dzięki nim możliwe jest opracowanie kompromisowego, akceptowanego przez różne grupy społeczne, programu działań.

Docelowo restrukturyzacja regionu zmierza do wykształcenia na obszarach poprzemysłowych nowych relacji funkcjonalno-przestrzennych z otoczeniem, zgodnie z zasadą zrównoważonego rozwoju:

- zmniejszenie negatywnego oddziaływania na środowisko naturalne;

- zachowanie najcenniejszych obiektów (zasobów materialnych);

- poprawa jakości życia społeczności lokalnej.

Największą trudnością jest umiejętne połączenie funkcji kulturalnych, komercyjnych i społecznych, właściwa integracja obiektu z otoczeniem (tkanką miejską). Stopień przekształcenia obiektu przemysłowego zależy od roli, jaką ma on odgrywać w dzielnicy czy też mieście. Może ono polegać jedynie na konserwacji lub rozbudowie, ale także na zmianie konstrukcji czy pełnej przebudowie. Rozwiązaniem może być tworzenie centrów wielofunkcyjnych. Przykładem takich działań jest otwarte niedawno Silesia City Center w Katowicach - centrum handlowe powstałe na terenie zlikwidowanej kopalni „Gottwald”, której zabytkowe budynki wkomponowano w kompleks. Jest to pierwsze tego typu rozwiązanie planistyczne na Śląsku. W skali miasta adaptacje zespołów przemysłowych zapobiegają dezintegracji przestrzeni miejskiej, zwiększając przestrzenie publiczne oraz zachowując wyjątkowy charakter i klimat architektury przemysłowej (Wowrzeczka 2000).

Kultura materialna od zawsze była bodźcem postępu technicznego i cywilizacyjnego społeczeństw, dlatego też nie można dopuścić, aby tak ważna sfera działalności gospodarczej nie została zachowana dla przyszłych pokoleń. Jest ona ilustracją ludzkich osiągnięć, marzeń i ideałów. Starając się ją zachować, wyrażamy także szacunek dla całej rzeszy górników, robotników. Trudno bowiem cywilizacyjnie rozwijać się krajowi, który nie pamięta o swoich poprzednikach, nie szanuje tego, czego dokonali.

\section{Literatura}

Chmura J., Lorenc M., Mikoś T., 2002, Opieka i ochrona zabytków podziemnych $w$ działalności Towarzystwa Hades - Polska, [w:] Ochrona zabytków techniki pod względem organizacyjnym, prawnym i finansowym - stan obecny i perspektywy, Zabrze.

Fletcher D., 1994, Ratowanie, restauracja i adaptacja opuszczonych budynków przemysłowych, [w:] M. Smoktunowicz (red.), Rewitalizacja zabytków techniki. Nowe życie w starych zakładach przemystowych, Warszawa.

„,Koncepcja utworzenia Muzeum Zabytkowej Kopalni ‘Ignacy’ ”. Zarząd Stowarzyszenia Zabytkowej Kopalni „Ignacy”, Rybnik 2000 [niepublikowane].

Konopka M., 1994, Obiekty przemystowe też moga być zabytkami, [w:] M. Smoktunowicz (red.), Rewitalizacja zabytków techniki. Nowe życie w starych zakładach przemystowych, Warszawa.

Lamparska-Wieland M., 2003, Charakterystyka ruchu turystycznego w kopalniach zabytkowych potudniowej Polski, [w:] II Konferencja. Ochrona Zabytków Górniczych. Aspekty organizacyjne, finansowe i prawne - stan obecny i perspektywy, Gliwice.

Strategia rozwoju turystyki $w$ województwie ślaskim na lata 2004-2013, Sejmik Województwa Śląskiego, Katowice 2004.

Wowrzeczka B., 2000: Przekształcenia zakładów przemystowych - wspótczesne tendencje, [w:] Architektura przemystowa i zabytki techniki na Ślasku w dobie restrukturyzacji, Katowice. 
The mining regions in the post-industrial transformation of Upper Silesia

In a few last decades the mining industry is gradually becoming a thing of the past. Mines are being closed down one by one and the whole mining regions are liquidated. More than two hundred years of history of the Silesian mining industry has left a great number of industrial monuments. The obsolete post-industrial infrastructure is nowadays becoming one of the sights of the region, attracting many visitors. It can co-create the multifunctionality of the Silesian region as a tourist attraction and take part in its restructuring. In Silesia, as in many European regions, mainly local communities and organizations deal with preservation and protection of the historic industrial structures. This article shows the examples of such activities and presents the historic mines, which are accessible to the tourists in the Silesian region. It also illustrates some other possibilities of using the mining structures, apart from tourism. 